\title{
Knowledge and Utilization of Iodized Salt and Associated Factors among Households of Fitche Town, Central Ethiopia, 2020: A Community based Cross-Sectional Study
}

\author{
Serkalem Worku ${ }^{1}$, Girma Garedew ${ }^{2 *}$, Leta Adugna ${ }^{2}$, Derara Girma ${ }^{2}$ and Hiwot Dejene ${ }^{2}$ \\ ${ }^{1}$ Santé Medical College, Addis Ababa, Ethiopia \\ ${ }^{2}$ Public Health Department, Salale University, Ethiopia
}

Submission: August 01, 2021; Published: September 29, 2021

*Corresponding author: Girma Garedew, Public Health Department, Salale University, Ethiopia

\begin{abstract}
Adequate knowledge and proper utilization of iodized salt in the household is a significant factor in the prevention of iodine deficiency disorders. This study was aimed at assessing knowledge and utilization of iodized salt and associated factors among the Fitche town community. A total of 470 individuals in the household were participated. About $58.6 \%$ of the respondents had good knowledge of iodized salt use and $52.6 \%$ use adequately iodized salt. Having higher monthly income [adjusted odds ratio $(\mathrm{AOR})=2.97,95 \%$ confidence interval $(\mathrm{CI}): 1.05-8.42]$, having family health insurance [AOR $=2.57$, 95\%CI:1.15-5.74] and being aware of iodine deficiency consequences [AOR=1.88, 95\%CI:1.03-3.40)] were significantly associated with proper utilization of iodized salt. Besides, acquiring health advice on iodized salt [AOR=2.20, 95\%CI:1.10-4.40] and educational status [AOR=0.14, 95\%CI:0.03-0.56] were shown significant association with the knowledge of respondents on iodized salt use. Even though knowledge of iodized salt use in the study area is higher as compared to other findings, the coverage of proper iodized salt utilization is less than the world health organization recommendation of iodized salt use in households. Therefore, promoting the knowledge and utilization of iodized salt should be strengthened. Additionally, routine testing and monitoring for iodine levels in salt sold in the markets and used by households have enormous benefits.
\end{abstract}

Keywords: Knowledge; Utilization; Iodine; Salt; Fitche; Ethiopia

Abbreviations: AOR=Adjusted Odds Ratio; COR=Crude Odds Ratio; KM=Kilometer; PPM=Parts Per Million

\section{Introduction}

Iodine is an essential micro-nutrient and dietary mineral which is required for human growth, development, and maintenance of normal levels of thyroid hormone synthesis [1]. For the past six decades, iodine deficiency has been recognized as a major public health problem, posing huge risks to the population's health and growth. According to a new global report on iodine status, the number of countries where iodine deficiency is a public health problem has halved over the past decade. However, 54 countries are still iodine-deficient [2]. World health organization (WHO) recommends all food-grade salt used in household and food processing should be fortified with iodine as a safe and effective prevention and control strategy for iodine deficiency disorders [3]. Salt is the most preferable and effective vehicle for distributing iodine to the public because it does not spoil and is consumed in a more predictable amount than most other commodities [4]. According to WHO, the recommended daily allowances of iodine intake is $90 \mathrm{mcg}$ for preschool children (0-59 months), $120 \mathrm{mcg}$ for schoolchildren (6-12 years), $150 \mathrm{mcg}$ for adolescents $(>12$ years) and adults, and $250 \mu \mathrm{g}$ for pregnant and lactating women [5]. Globally, the problem of iodine deficiency was recognized as a major public health problem affecting billions of people with less developed countries affected more than the rest of the world [6]. In 2020, 28 countries have insufficient iodine in their diets worldwide [7]. Likewise, nearly 1 billion people did not consume iodized salt in 2018 [8]. Insufficient daily consumption of iodine causes a range of functional and developmental abnormalities collectively known as Iodine Deficiency Disorders (IDD) [1]. This Disorder refers to all the ill-effects of iodine deficiency including mental retardation, goiter, reproductive failures such as abortions, congenital abnormalities and stillbirths, mental retardation, impaired mental function [9] hypothyroidism, intellectual disability, psychomotor defects, hearing, and speech impairment [3]. Universal Salt Iodization (USI) is a key strategy proposed by WHO, UNICEF, and ICCIDD to eliminate IDD at the population level [3]. In reality, even though salt iodization programs with high 
coverage exist, the programs remain vulnerable to changes in the knowledge and practice of the community.

In Ethiopia, the practice of adequate iodized salt use showed a noticeable growth from $15 \%$ in 2011 to $89 \%$ in 2016 [10,11]. However, inconsistencies of the practice are detected among residences and economic standing [12]. As an illustration, iodized salt utilization is highest in Addis Ababa City [12] and lowest in northern Ethiopia [13]. Concerning the knowledge of iodized salt utilization, the highest prevalence was observed in Addis Ababa City [12] and the lowest was observed in the southern part of the country [14].

On top of the observed discrepancy of iodized salt practice and knowledge at household in the country, further studies to identify the knowledge and awareness of the general population about the use of iodized salt are indicated essential to address barriers in general [4] and particularly in Ethiopia where there are needs to improve coverage of adequately iodized salt [15]. Additionally, the knowledge and practice of iodized salt use appear unknown in Fitche town households. So, the current study aimed at filling this evidence gap by providing significant information on the knowledge and utilization of iodized salt and the reason behind it.

\section{Materials and Methods}

\section{Study design and setting}

A community-based cross-sectional study was conducted in Fitche town, Oromia regional state from May 01 to June 30/2020. Fitche is the capital town of the North Shewa zone, Oromia regional state, and found to the North of Addis Ababa, the capital city of Ethiopia. According to data obtained from the town municipality, the town's total population in 2019 is estimated to be 44,265 , of which 21,000 were males. There are 11,020 households in the town, which is divided into 4 kebeles (the smallest administrative unit).

\section{Study participants and sampling procedures}

The source populations were all households in Fitche town. The member of a selected household who is responsible for food preparation and aged $\geq 18$ was considered as a study unit. Individuals (study units) who resided in the study area for at least 6 months were included in the study. The sample size was determined by using single proportion formula, $\mathrm{n}=\left(\left(\mathrm{Z}_{1-\alpha / 2}\right)^{2 *} \mathrm{pq} /\right.$ $\mathrm{d}^{2}$ ), considering the following assumptions: $52.8 \%$ proportion of good knowledge of iodized salt utilization [14], 95\% level of confidence, $5 \%$ marginal error, and $15 \%$ non-response rate. Thus, the final sample size was 440 . All four administrative kebele in the town were included in the study. Preliminary household enumeration (census) was done to identify eligible households. Then, the total sample size was allocated to each kebele using proportion allocation to size based on the total number of eligible households in each kebele. Finally, the required sample from each kebele was selected by a simple random sampling technique using a computer-generated number in SPSS.

\section{Data collection technique and instruments}

Data was collected using a pretested structured, interview administered questionnaire, and a rapid field iodine test kit was used to collect data from the study participants. Two BSc nurses who have experience in supervision and four data collectors female BSc nurses participated in the study. Rapid test kits were used as semi-quantitative estimations of iodine content. Rapid field iodine test kits manufactured by MINI KITS INTERNATIONAL, India were used to test the iodine content of household salt. A small amount of household salt was obtained from each respondent and Rapid Field Iodine Test Kits were used to test the iodine content. The test was done by adding two drops of the test solution to each salt sample and this was expected to produce light or deep violet color within one minute depending on the iodine content of the salt. The color of the salt was compared to the color chart provided to determine the iodine content. On samples where no color appeared after one-minute, fresh salt samples were obtained and about five drops of the test solution were added. The color was again compared to the color chart to determine the iodine content. Depending on this test, if the iodine content in the salt is $\geq 15 \mathrm{ppm}$ then the salt was taken as adequately iodized. But, if the iodine content in the salt is $<15 \mathrm{ppm}$ then salt is inadequately iodized $[16,17]$. After validation of whether the salt is iodized or not, the practice of iodized salt at that specific house was determined and classified as practicing and not. Utilization status was classified as proper and improper after determining whether individuals in the household were using adequately iodized salt $(\geq 15 \mathrm{ppm}$ ) iodine and use salt after cooking finished. Additionally, knowledge status was determined by using a nine-item question regarding the benefits and risk iodine deficiencies for participants to choose. Those who were able to answer above 50\% were categorized as having good knowledge while those who answered less than five correct responses were categorized as having poor knowledge. Additionally, the questionaries consist of different socio-demographic, health system-related, and individual-level factors.

\section{Operational Definition}

\section{Knowledge of iodized salt}

Respondents who answer half and more than half of the knowledge-related questions were considered as $[13,16,17]$.

\section{Utilization of iodized salt}

Refers to a respondent who used adequately iodized salt $(\geq 15 \mathrm{ppm})$ by using a rapid test kit $[3,17]$.

\section{Data analysis procedures}

After data collection, each questionnaire was checked for completeness and consistency of the information obtained from the respondent. Then, the data were entered into EpiData manager version 4.4.6 and exported to SPSS version 24 for analysis. Descriptive analysis was done to describe the variable 


\section{Juniper Online Journal of Public Health}

based on their nature. Bivariable analysis was conducted to see the association between dependent and different explanatory variables. Then, all variables with $p$-value $\leq 0.25$ were considered as a candidate for the multivariable logistic regression model. Backward stepwise multivariable logistic regression was used to identify the predictor variables. Adjusted Odds Ratio (AOR) with the corresponding 95\% Confidence Interval were estimated to show the strength of association. Finally, variables with a p-value $<0.05$ were considered statistically significant.

\section{Data quality management}

The questionnaires were initially designed in English and translated into the local language (Afan Oromo) by experts, and then translated back to English by a third person to check for consistency. Data collection instruments were pretested on $10 \%$ of the total sample size in Hambiso town which is $12.2 \mathrm{~km}$ far from the study area. Accordingly, necessary measures were taken to correct the observed error before entering the actual data collection process. Also, data collectors and supervisors were trained for two days on the techniques of data collection before starting data collection. The functionality of the iodine field test kit was checked during the entire process and proper handling of the kit was also maintained.

\section{Results}

\section{Socio-demographic characteristics of the respondents}

A total of 430 respondents were participated in the study yielding a $97.3 \%$ response rate. The mean age of the respondents was 40.48 years with $(\mathrm{SD}=10.88)$. One-third of the respondents belong to age 25-34 years. The majority of the respondents, $149(34.8 \%)$ were orthodox religion followers and 264(61.5\%) attend formal education with $98(22.7 \%)$ of them reported not having a job outside the house. About 303(70.8\%) households mentioned husband as a head of a family with nearly one third $145(33.9 \%)$, and $101(23.6 \%)$ of the participant stating husband and wife were the last decision-makers respectively. In about $134(31.3 \%)$ and $48(11.2 \%)$ of the household joint husband and wife and relatives were mentioned as the last decision-maker at the household level respectively. Almost half, 213(49.6\%) of the household had using iodized salt for less than five years and $195(50.8 \%)$ were using it for more than ten years. About $242(62.4 \%)$ of the household store iodized salt at home for a period lasting less than two months and the rest $146(37.4 \%)$ store for more than two months (Table 1).

Table 1: Sociodemographic characteristics of the respondents, Fitche town, Oromia regional state, central Ethiopia, 2020.

\begin{tabular}{|c|c|c|c|}
\hline Variables & Category & Frequency (n) & Percentage (\%) \\
\hline \multirow{4}{*}{ Age } & $18-24$ & 15 & 3.5 \\
\hline & $25-34$ & 142 & 33.2 \\
\hline & $35-44$ & 123 & 28.7 \\
\hline & $\geq 45$ & 148 & 34.6 \\
\hline \multirow{4}{*}{ Religion } & No religion & 65 & 15.2 \\
\hline & Orthodox & 149 & 34.8 \\
\hline & Protestant & 108 & 25.2 \\
\hline & Muslim & 106 & 24.8 \\
\hline \multirow{5}{*}{ Marital status } & Single & 62 & 14.5 \\
\hline & Married & 226 & 52.8 \\
\hline & Divorce & 46 & 10.7 \\
\hline & Widowed & 24 & 5.6 \\
\hline & Separated & 70 & 16.4 \\
\hline \multirow{5}{*}{ Occupation } & Government employ & 89 & 20.8 \\
\hline & Merchant & 85 & 19.9 \\
\hline & Daily laborer & 97 & 22.7 \\
\hline & Farmer & 60 & 14 \\
\hline & Housewife & 97 & 22.7 \\
\hline \multirow{3}{*}{ Income } & $<500$ & 58 & 13.6 \\
\hline & $500-1000$ & 60 & 14 \\
\hline & $\geq 1000$ & 310 & 72.4 \\
\hline \multirow{3}{*}{ Family size } & Less than five & 201 & 47 \\
\hline & Five to Ten & 113 & 26.4 \\
\hline & Greater or equals to Ten & 114 & 26.6 \\
\hline
\end{tabular}




\section{Juniper Online Journal of Public Health}

\begin{tabular}{|c|c|c|c|}
\hline \multirow{3}{*}{$\begin{array}{c}\text { Number of room in the } \\
\text { house }\end{array}$} & Less than five & 336 & 78.5 \\
\cline { 2 - 4 } & Five to Ten & 67 & 15.7 \\
\cline { 2 - 4 } & Greater or equals to Ten & 25 & 5.8 \\
\cline { 2 - 4 } Food cooking place & Use separate room & 123 & 28.7 \\
\cline { 2 - 4 } & Outside the house & 96 & 22.4 \\
\hline
\end{tabular}

\section{Health system-related characteristics}

In this study, about $225(52.6 \%)$ of the respondents reside within a five-kilometer diameter from a health facility with slightly more than half, 228(53.0\%) of the respondent accessed family health insurance service coverage. Out of the total respondents, 193(45.1\%) stated as they have been received advice from health facilities on iodized salt (Table 2).

Table 2: Health system-related characteristics of the household, Fitche town, Oromia regional state, central Ethiopia, 2020.

\begin{tabular}{|c|c|c|c|}
\hline Variables & Category & Frequency (n) & Percentage $(\%)$ \\
\hline \multirow{2}{*}{ Distance from health facility } & $<5 \mathrm{Km}$ & 225 & 52.6 \\
\hline & $\geq 5 \mathrm{Km}$ & 203 & 47.4 \\
\hline \multirow{2}{*}{ Community health worker (HEW) } & Available & 309 & 72.2 \\
\hline & Not available & 119 & 27.8 \\
\hline \multirow{2}{*}{ HEW engagement in routine home visit } & Engaged & 151 & 35.3 \\
\hline & Not engaged & 277 & 64.7 \\
\hline \multirow{2}{*}{ Received advice from health facilities on iodized salt } & Yes & 193 & 45.1 \\
\hline & No & 235 & 54.9 \\
\hline \multirow{2}{*}{ Family health insurance } & Insured & 227 & 53 \\
\hline & Not insured & 201 & 47 \\
\hline
\end{tabular}

\section{Knowledge of the respondents on the iodized salt use}

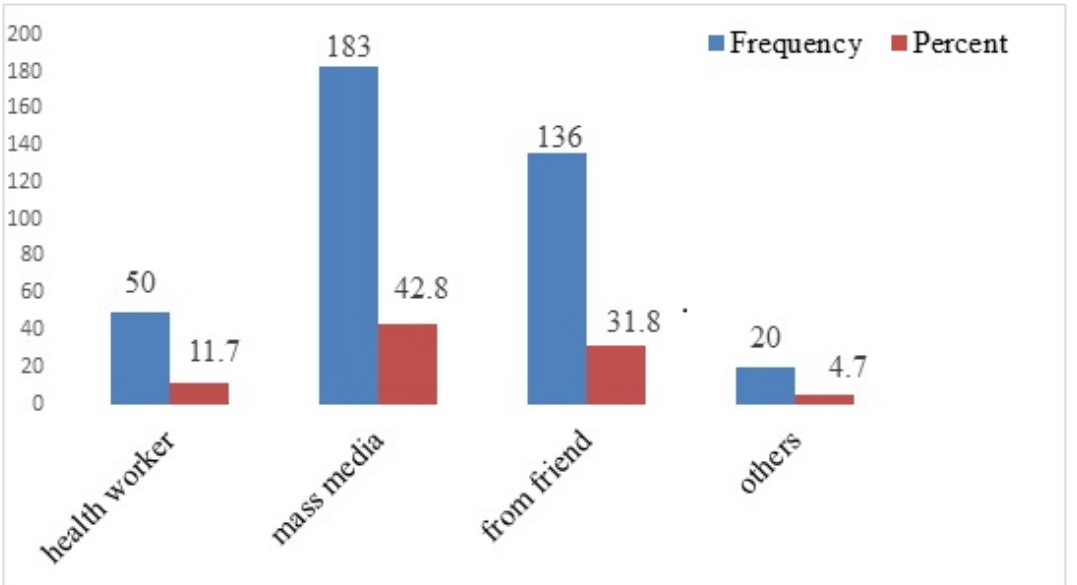

Figure 1: Information source on iodized salt use among respondent of Fitche town community, Oromia regional state, central Ethiopia, 2020 iodized.

This study demonstrated that more than half, $58.6 \%$ of the respondents have good knowledge of the benefit of iodized salt use. About $304(71.0 \%)$ of the participants had heard iodine deficiency with only $115(37.8 \%)$ of the participants stating some form of health defect/consequences resulting from iodine deficiency. Related to the care of iodized salt more than half 


\section{Juniper Online Journal of Public Health}

(55.0\%) of respondents revealed that iodized salt needs more care than other commonly used types of salt. On the other hand, about $82(32.8 \%), 84(33.6 \%)$, and $78(31.2 \%)$ of the respondents stated that iodized salt must be stored far from heat, moisture, and sunlight respectively (Table 3). The study also revealed that various sources of awareness related to the importance of iodized salt use among the respondents who have awareness. Accordingly, the majority, 183(42.8\%) of the respondents mentioned mass media as their major source of information (Figure 1). On the other hand, a series of questions have been asked the respondents on the importance of iodized salt who were initially aware of iodized salt. Accordingly, the majority $101(26.0 \%)$ respond as it prevents iodine deficiency disorder (IDD) followed by goiter prevention 93(23.9\%) (Figure 2).

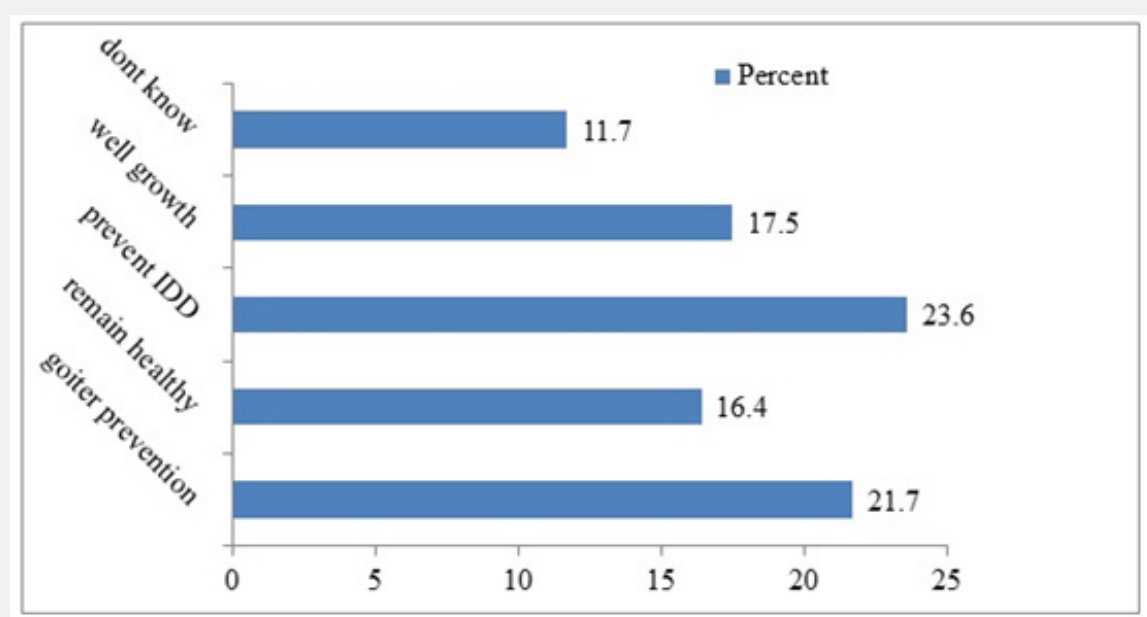

Figure 2: importance mentioned for the use of iodized salt among respondent, Fitche town, Oromia regional state, central Ethiopia, 2020.

Table 3: Knowledge and awareness status of the respondent on iodized salt among Fitche town community, Oromia regional state, Central Ethiopia, 2020.

\begin{tabular}{|c|c|c|c|}
\hline Variables & Category & Frequency (n) & Percentage (\%) \\
\hline \multirow{2}{*}{ Ever heard of iodine deficiency } & Yes & 304 & 71 \\
\hline & No & 124 & 29 \\
\hline \multirow{2}{*}{ Aware of the consequences of iodine deficiency } & Yes & 115 & 37.8 \\
\hline & No & 189 & 62.2 \\
\hline \multirow{2}{*}{ Aware of iodized salt } & Yes & 389 & 90.9 \\
\hline & No & 39 & 9.1 \\
\hline \multirow{2}{*}{ Aware of the consequences of not using iodized salt } & Yes & 255 & 65.4 \\
\hline & No & 135 & 34.6 \\
\hline \multirow{2}{*}{$\begin{array}{l}\text { The iodized salt container is labeled with iodine level and expiry } \\
\text { date }\end{array}$} & Yes & 165 & 42.4 \\
\hline & No & 224 & 57.6 \\
\hline \multirow{2}{*}{ Iodized salt needs more care than other forms of salt } & Yes & 214 & 55 \\
\hline & No & 175 & 45 \\
\hline \multirow{2}{*}{ Iodized salt loses its content if kept near heat } & Yes & 287 & 73.8 \\
\hline & No & 102 & 26.2 \\
\hline \multirow{2}{*}{ Iodized salt loses its content if left uncovered } & Yes & 184 & 47.3 \\
\hline & No & 205 & 52.7 \\
\hline \multirow{2}{*}{ Iodized salt taste differs from other forms } & Yes & 175 & 45 \\
\hline & No & 214 & 55 \\
\hline \multirow{3}{*}{ Meaning of iodized salt } & $\begin{array}{c}\text { Ordinary salt with a } \\
\text { small amount of iodized } \\
\text { salt }\end{array}$ & 157 & 40.4 \\
\hline & Common salt & 147 & 37.7 \\
\hline & Don't know & 85 & 21.9 \\
\hline
\end{tabular}




\section{Juniper Online Journal of Public Health}

\section{Utilization practice of iodized salt in fitche town community}

The practice/utilization of adequately iodized salt i.e., iodine $(\geq 15 \mathrm{ppm}$ ) in Fitche town household was $52.6 \%$. out of the total participants, $10.3 \%$ was not having any iodine content $(0 \mathrm{ppm})$ and $37.1 \%$ having less amount of iodine $(<15 \mathrm{ppm})$ (Table 4$)$.

Table 4: lodized salt practice and utilization status among household respondent of Fitche town community, Oromia regional state, Central Ethiopia, 2020

\begin{tabular}{|c|c|c|c|}
\hline Variables & Category & Frequency (n) & Percentage $(\%)$ \\
\hline \multirow{2}{*}{ Salt type currently used } & Iodized packed salt & 378 & 88.3 \\
\hline & Coarse salt (non-packed) & 50 & 11.7 \\
\hline \multirow{2}{*}{ Exposing salt to sunlight } & Yes & 148 & 38 \\
\hline & No & 241 & 62 \\
\hline \multirow{2}{*}{ Washing for impurity } & Yes & 82 & 21.17 \\
\hline & No & 307 & 78.9 \\
\hline \multirow{4}{*}{ Salt storage place } & Dry area & 173 & 44.5 \\
\hline & Moist area & 120 & 30.8 \\
\hline & Near fire & 88 & 22.6 \\
\hline & Other & 8 & 2.1 \\
\hline \multirow{3}{*}{ Time salt is added during cooking food } & Early during cooking & 133 & 34.2 \\
\hline & Middle of food cooking & 94 & 24.2 \\
\hline & Late after cooking & 162 & 41.6 \\
\hline \multirow{2}{*}{ Distance traveled to buy iodized salt } & Less than five $\mathrm{Km}$ & 330 & 85.1 \\
\hline & $\geq$ five $\mathrm{Km}$ & 58 & 14.9 \\
\hline \multirow{2}{*}{ Salt container } & Covered & 290 & 74.6 \\
\hline & Not covered & 99 & 25.4 \\
\hline \multirow{3}{*}{ A place to buy iodized salt } & Village shop & 182 & 46.9 \\
\hline & Near supermarket & 72 & 18.3 \\
\hline & Market & 118 & 30.4 \\
\hline
\end{tabular}

\section{Reasons for non-using of iodized salt}

From the total respondents, $71 \%$ of the respondent claimed that they heard about iodized salt with around $88.3 \%$ revealed as they are using iodized packed salt. But the other, $11.7 \%$ reported that they are using coarse salt. Being expensive $(22 \%)$ and not being salty (24\%) were the main reason mentioned for not using iodized salt (Figure 3).

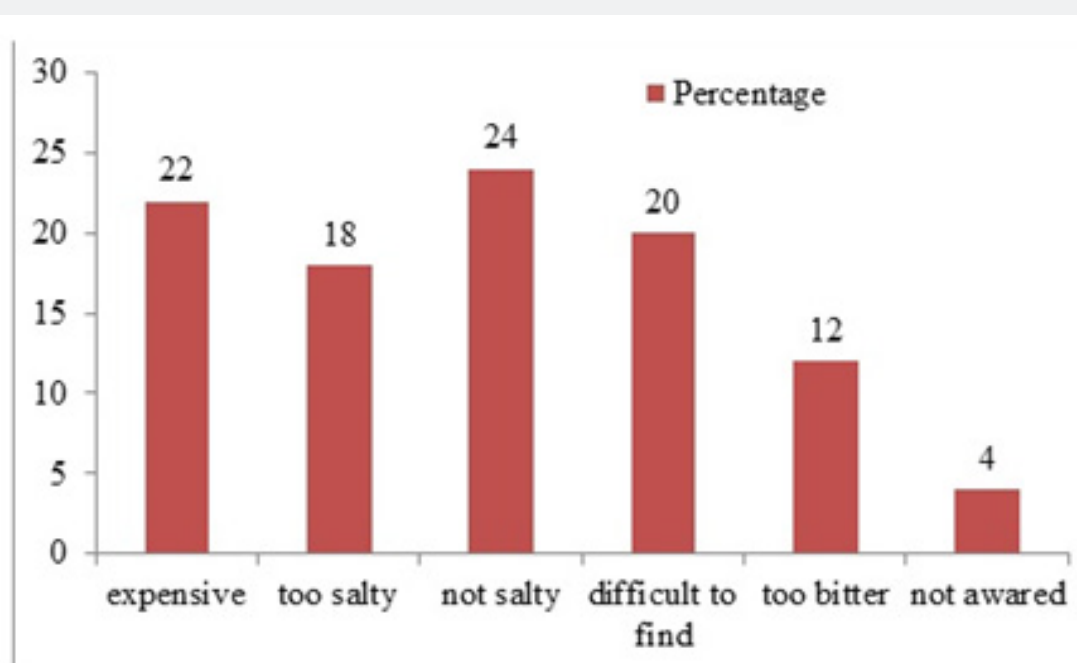

Figure 3: The main reason mentioned for not using iodized salt in Fitche town community, Oromia regional state, central Ethiopia, 2020. 
Factors associated with knowledge and utilization of iodized salt

On multivariable logistic regression analysis covariates such as educational status and receive advice on iodized salt at health institution, were significantly associated with knowledge of individuals. Accordingly, individuals who did not attend any formal education were $79 \%$ less likely knowledgeable on iodized salt use as compared to those who did attend secondary education (AOR=0.21, 95\%CI:0.06, 0.78). Individual who received health advice on iodized salt was more than two times more knowledgeable compared to those who did not receive
$(\mathrm{AOR}=2.20,95 \% \mathrm{CI}: 1.10,4.40)$ (Table 5). Furthermore, income level and being aware of the consequences of iodine deficiency were significantly associated with proper utilization of iodized salt. Accordingly, the odds of proper iodized salt utilization were about three times higher in those individuals earning greater than 1000 birr as compared to those individuals earning less than 500 birrs (AOR=2.97, 95\%CI:1.05, 8.42). The odds of proper iodized salt utilization were almost two times higher among individuals who have been aware of the consequences of iodine deficiency compared to those who have not been aware of iodine deficiency consequences (AOR=1.88, 95\%CI:1.03, 3.40) (Table 5).

Table 5: Factors associated with knowledge of iodized salt use among household in Fitche town community, Oromia regional state, central Ethiopia, 2020.

\begin{tabular}{|c|c|c|c|c|c|c|}
\hline \multirow[b]{2}{*}{ Variables } & \multicolumn{2}{|c|}{ Knowledge } & \multirow[b]{2}{*}{ COR $(95 \% \mathrm{CI})$} & \multirow[b]{2}{*}{ P-Value } & \multirow[b]{2}{*}{ AOR $(95 \% \mathrm{CI})$} & \multirow[b]{2}{*}{ P-Value } \\
\hline & Good & Poor & & & & \\
\hline \multicolumn{7}{|c|}{ Health insurance coverage } \\
\hline Yes & $149(65.6 \%)$ & $78(34.4 \%)$ & $1.85(1.25,2.73)$ & 0.002 & $0.75(0.30,1.86)$ & 0.546 \\
\hline No & $102(50.7 \%)$ & $99(49.3 \%)$ & 1 & & 1 & \\
\hline \multicolumn{7}{|c|}{ Involvement in HDA } \\
\hline Yes & $145(66.2 \%)$ & $74(33.8 \%)$ & $1.90(1.28,2.81)$ & 0.001 & $1.61(0.65,3.97)$ & 0.294 \\
\hline No & $106(50.7 \%)$ & $103(49.3 \%)$ & 1 & & 1 & \\
\hline \multicolumn{7}{|c|}{ Advice on iodized salt } \\
\hline Yes & $126(65.3 \%)$ & $67(34.7 \%)$ & $1.65(1.11,2.44)$ & 0.012 & $2.20(1.10,4.40)$ & $0.026^{*}$ \\
\hline No & $125(53.2 \%)$ & $110(46.8 \%)$ & 1 & & 1 & \\
\hline \multicolumn{7}{|c|}{ Availability of HEW } \\
\hline Yes & $191(61.8 \%)$ & $118(38.2 \%)$ & $1.59(1.03,2.43)$ & 0.033 & $1.63(0.69,3.87)$ & 0.264 \\
\hline No & $60(50.4 \%)$ & $59(49.6 \%)$ & 1 & & 1 & \\
\hline \multicolumn{7}{|c|}{ Engagement of HEW in community health work } \\
\hline Yes & $99(65.6 \%)$ & $52(34.4 \%)$ & $1.56(1.03,2.36)$ & 0.032 & $0.79(0.36,1.72)$ & 0.566 \\
\hline No & $152(54.9 \%)$ & $125(45.1 \%)$ & 1 & & 1 & \\
\hline \multicolumn{7}{|c|}{ Income level } \\
\hline$<500 \mathrm{ETB}$ & $24(41.4 \%)$ & $34(58.6 \%)$ & 1 & & 1 & \\
\hline 500-1000ЕТВ & $37(61.7 \%)$ & $23(38.3 \%)$ & $2.24(1.26,3.96)$ & 0.006 & $1.26(0.35,4.54)$ & 0.714 \\
\hline$\geq 1000$ & $190(61.3 \%)$ & $120(37.8 \%)$ & $0.98(0.55,1.73)$ & 0.956 & $1.88(0.65,5.38)$ & 0.239 \\
\hline \multicolumn{7}{|c|}{ Duration iodized salt used } \\
\hline Less than five yrs & $105(54.7 \%)$ & $87(45.3 \%)$ & 1 & & 1 & \\
\hline $5-10$ yrs & $34(61.8 \%)$ & $21(38.2 \%)$ & $0.55(0.35,0.87)$ & 0.011 & $0.47(0.21,1.00)$ & 0.052 \\
\hline Greater than ten yrs & $96(68.6 \%)$ & $44(31.8 \%)$ & $0.74(0.38,1.42)$ & 0.396 & $0.82(0.32,2.10)$ & 0.688 \\
\hline \multicolumn{7}{|c|}{ Education status } \\
\hline No education & $19(28.8 \%)$ & $47(71.2 \%)$ & 1 & & 1 & \\
\hline Read and write only & $49(49.5 \%)$ & $50(50.5 \%)$ & $0.41(0.21,0.80)$ & 0.009 & $0.41(0.12,1.35)$ & 0.144 \\
\hline Primary & $35(38.9 \%)$ & $55(61.1 \%)$ & $0.63(0.32,1.25)$ & 0.191 & $0.37(0.10,1.31)$ & 0.126 \\
\hline Secondary & $46(44.2 \%)$ & $58(55.8 \%)$ & $0.51(0.26,0.98)$ & 0.045 & $0.21(0.06,0.78)$ & $0.019^{*}$ \\
\hline Tertiary & $28(40.6 \%)$ & $41(59.1 \%)$ & $0.59(0.28,1.21)$ & 0.152 & $0.14(0.03,0.56)$ & $0.005^{* *}$ \\
\hline
\end{tabular}


Table 6: Factors associated with utilization of iodized salt among household in Fitche town community, Oromia regional state, central Ethiopia, 2020.

\begin{tabular}{|c|c|c|c|c|c|c|}
\hline \multirow{2}{*}{ Variable } & \multicolumn{2}{|c|}{ Utilization } & \multirow{2}{*}{ COR $(95 \% C I)$} & \multirow{2}{*}{ P-Value } & \multirow{2}{*}{ AOR (95\%CI) } & \multirow{2}{*}{ P-Value } \\
\hline & Proper & Not proper & & & & \\
\hline \multicolumn{7}{|c|}{ Knowledge of iodized salt } \\
\hline Good & $89(37.7 \%)$ & $147(62.3 \%)$ & $2.48(1.53,4.00)$ & 0.001 & $1.76(0.77,4.02)$ & 0.176 \\
\hline Poor & $30(19.6 \%)$ & $123(80.4 \%)$ & 1 & & 1 & \\
\hline \multicolumn{7}{|c|}{ Income level } \\
\hline$<500$ & $10(19.2 \%)$ & $42(80.8 \%)$ & 1 & & 1 & \\
\hline $500-1000$ & $18(34.6 \%)$ & $34(65.4 \%)$ & $2.22(0.90,5.44)$ & 0.08 & $6.97(1.97,24.68)$ & $0.003^{* *}$ \\
\hline$\geq 1000$ & $91(31.9 \%)$ & $194(68.1 \%)$ & $1.97(0.94,4.10)$ & 0.07 & $2.97(1.05,8.42)$ & $0.040 *$ \\
\hline \multicolumn{7}{|c|}{ Involvement in HDA } \\
\hline Yes & $86(40.4 \%)$ & $127(59.6 \%)$ & $2.93(1.83,4.68)$ & 0.001 & $1.77(0.82,3.85)$ & 0.145 \\
\hline No & $33(18.8 \%)$ & $143(81.3 \%)$ & 1 & & 1 & \\
\hline \multicolumn{7}{|c|}{ Family Health insurance } \\
\hline Insured & $95(43.6 \%)$ & $123(56.4 \%)$ & $4.73(2.84,7.86)$ & 0.001 & $2.57(1.15,5.74)$ & $0.020^{*}$ \\
\hline Not insured & $24(14.0 \%)$ & $147(86.0 \%)$ & 1 & & 1 & \\
\hline \multicolumn{7}{|c|}{ Advice on iodized salt use at health facilities } \\
\hline Advised & $68(37.0 \%)$ & $166(63.0 \%)$ & $1.77(1.14,2.73)$ & 0.01 & $1.07(0.57,2.00)$ & 0.829 \\
\hline Not Advised & $51(24.9 \%)$ & $154(75.1 \%)$ & 1 & & 1 & \\
\hline \multicolumn{7}{|c|}{ Routine home visit by HEW } \\
\hline Yes & $58(39.5 \%)$ & $89(60.5 \%)$ & $1.93(1.24,3.00)$ & 0.003 & $0.82(0.41,1.61)$ & 0.565 \\
\hline No & $61(25.2 \%)$ & $181(74.8 \%)$ & 1 & & 1 & \\
\hline \multicolumn{7}{|c|}{ Head of household } \\
\hline Husband & $92(33.6 \%)$ & $182(66.4 \%)$ & 1 & & 1 & \\
\hline Wife & $27(23.5 \%)$ & $88(76.5 \%)$ & $0.60(0.36,1.00)$ & 0.05 & $1.49(0.74,2.99)$ & 0.257 \\
\hline \multicolumn{7}{|c|}{ Aware of iodine deficiency } \\
\hline Aware & $51(46.4 \%)$ & $59(53.6 \%)$ & $2.14(1.25,3.66)$ & 0.005 & $1.88(1.03,3.40)$ & $0.037^{*}$ \\
\hline Not aware & $47(27.2 \%)$ & $126(72.2 \%)$ & 1 & & 1 & \\
\hline
\end{tabular}

COR=Crude Odds Ratio; AOR=Adjusted Odds Ratio; $\mathrm{Cl}=$ Confidence Interval; *significant at $p$-value $<0.05$; **significant at $p$-value $<0.01$.

\section{Discussion}

This study was aimed to assess the knowledge and utilization of iodized salt in Fitche town community. In this study, 58.6\% of the respondents have good knowledge of the use of iodized salt. This finding is in line with studies conducted in Ethiopia (63.8\%) [18], Sudan (56\%) [19] and India (56.2\%) [20]. However, it is higher than the study conducted in different parts of Ethiopia including Mecha district (28.5\%) [21], Wolaita Sodo (44.7\%) [22], Arba Minch (52.8\%) [14] and Debreberhan (53\%) [23]. Demographical proximity of Fitche town to the center of the country may increase the chance of accessing information helping in knowledge improvement. Besides, the current study has enrolled only urban dwellers which was found to increase the knowledge level [22]. In contrast, this finding is lower than the study conducted in Addis Ababa (78\%) [12], Axum (80\%) [24], Ghana (72\%) [25], and India (64.6\%) [26]. The variation may also be due to differences in awareness creation and educational activities [14]. The differences might be due to iodized salt availability and accessibility in the local market and monitoring concerning the use of iodized salt in those areas [13]. About $52.6 \%$ of households in the study area were practicing adequately iodized salt for food preparation. This finding is comparable with the study done in Kore town (56.6\%) [13]. On the other hand, this finding is higher than the studies conducted in Wolaita (37.7\%) [27], Dabat district (33.2\%) (16), Gondar (28.9\%) [28], Benishangul Gumuz (26.1\%) [29], Laelay Maychew District (33\%) [30], and zuway (30.7\%) [31]. This discrepancy could be correlated to a change in the time when the studies were done [32]. As evidence from the Ethiopian demographic and health survey, the coverage of iodized salt increased from $28.4 \%$ in 2000 to $89 \%$ in 2016 [11]. In opposite to the above, this finding is lower than the study done in Saudi Arabia (95.2\%) [33] and India (83.1\%) [34]. The difference could be due to iodine deficiency has been recognized as a major public health problem in Ethiopia as compared to other countries where the studies have been conducted. Beyond assessing knowledge and utilization of iodized salt, this study also points out predictors 


\section{Juniper Online Journal of Public Health}

of knowledge and utilization of iodized salt. Accordingly, receiving health counsel on iodized salt use was identified as a predictor of knowledge in this population. This might be because health counsel/education has a positive impact on knowledge [35].

The educational status of the respondents was also found to be an independent predictor of knowledge on iodized salt use. This finding was in line with the studies conducted in Arba Minch [14] and Laelay Maychew district [30]. This could be because educated respondents have learned and could read about the importance of iodized salt. This study also identifies independent predictors of proper utilization of iodized salt. So, earning high monthly income was identified as an independent predictor of proper utilization of iodized salt. This finding is in line with the findings from Arba Minch town [14] and Addis Ababa [17]. This might be due to the reasons that families with high income can buy packed salts and have better information about iodized salt [17]. Moreover, family insurance coverage was another factor identified as a predictor of proper utilization of iodized salt. This is possibly due to the insured family have a higher chance of obtaining health-related information which might help them to practice iodized salt utilization properly. In this study, higher odds of proper utilization of salt were observed among households who have awareness about iodine deficiency disorder. This finding is supported by the study Laelay Maychew District [30]. This might be due to the fact that having awareness on how iodine deficiency affects health help to give due emphasis on its proper utilization.

\section{Conclusion}

Even though knowledge of iodized salt use in this community is higher as compared to other findings, the coverage of proper iodized salt utilization is less than $90 \%$ world health organization's recommendation of iodized salt use in the household [36]. Advice on iodized salt and education status were found to affect the knowledge of iodized salt use at the household level, while income level, family health insurance, and iodine deficiency awareness were independently associated with iodized salt use. Therefore, the town health facilities should provide health education programs to promote the knowledge and consumption of iodized salt. Additionally, routine testing and monitoring for iodine levels in salt sold in the markets and used by households are essential.

\section{Acknowledgments}

We would like to thank the Fitche town administration and health office for their support and provision of relevant information to do the study. Also, our deepest gratitude goes to the study participants, data collectors and supervisors for their priceless cooperation.

\section{Conflict Interests}

There is no conflict of interests among the authors

\section{References}

1. (2020) CDC. Nutrition: Micronutrient Facts.
2. (2020) World Health Organization. Micronutrient deficiencies: Iodine deficiency disorders.

3. (2019) World Health Organization. Iodization of salt for the prevention and control of iodine deficiency disorders.

4. WHO (2014) Fortification of food-grade salt with iodine for the prevention and control of iodine deficiency disorders. 1-43.

5. WHO (2014) Assessment of iodine deficiency disorders and monitoring their elimination: A guide for programme managers. $\left(3^{\text {rd }}\right.$ edition).

6. Pearce EN, Andersson M, Zimmermann MB (2013) Global Iodine Nutrition: Where Do We Stand in 2013?. Thyroid 23(5): 523-528.

7. Iodine Global Network (2020) Global Scorecard of iodine nutrition in 2020: optimal iodine intake in 131 countries. IDD Newsl.

8. UNICEF (2018) Iodine UNICEF Data.

9. Kapil U (2007) Health consequences of iodine deficiency. Sultan Qaboos Univ Med J 7(3): 267-272.

10. Addis Ababa (2012) Ethiopia Demographic and Health Survey 2011. ICF International, Calverton, Maryland, USA.

11. Addis Ababa (2016) Ethiopia Demographic and Health Survey 2016. Central Statistical Agency (CSA) and ICF Rockville, Maryland, USA.

12. Bazezew MM, Yallew WW, Belew AK (2018) Knowledge and practice of iodized salt utilization among reproductive women in Addis Ababa City. BMC Res Notes 11(1): 1-8.

13. March B, Initiative M, Gebretsadikan TM, Troen AM, Obssie GF, et al. (2020) Availability of adequately iodized in Northwest Ethiopia: A cross-sectional study. PLoS One 8(1): 1-9.

14. Dessu S, Dawit Z, Alemu G (2018) Assessment of Knowledge on Iodized Salt Utilization and Associated Factors among Households in Arba Minch Town Southern Ethiopia. Int J Res Stud Med Heal Sci 3(12): 1 .

15. UNICEF (2019) Comprehensive Nutrient Gap Assessment (Conga): findings for children 6-23 months in Ethiopia.

16. 16. Abebe Z, Tariku A, Gebeye E (2017) Availability of adequately iodized in Northwest Ethiopia: A cross-sectional study. Arch Public Heal 75(1): 1-9.

17. Ayigegn H, Wolde T, Geleta D, Haile K, Alemu A, et al. (2020) Adequately Iodized Salt and Associated Factors at Household Level in Kolfe keraniyo Sub-city Addis Ababa Ethiopia. 8(2): 30-36.

18. Yazew T (2020) Availability of Adequately Iodized Salt at Household Level and Its Associated Factors in Horro Woreda, Horro Guduru Wollega Zone Oromia Ethiopia. Pathol Lab Med 4(1): 20.

19. Elmanssur AEA, Elnour SA, Elmosaad YMA (2017) Knowledge and Attitude of Population Towards Iodized Salt in Shendi Locality River Nile State in Sudan. Eur Sci Journal ESJ 13(6): 312.

20. Datta A, Karmakar N, Nag K, Singha S (2018) A Study on Knowledge, Attitude and Practices Regarding Household Consumption of Iodized Salt among Selected Urban Women of Tripura India 12(11): 16-20.

21. Tariku WB (2019) Knowledge and Utilization of Iodized Salt and Its Associated Factors at Household Level in Mecha District Northwest Ethiopia.

22. Haji Y, Abdurahmen J, Paulos W (2017) Knowledge and Perception of Consumption of Iodized Salt among Food Handlers in Southern Ethiopia. Food Nutr Bull 38(1): 92-102.

23. Mulu T (2019) Assessment of knowledge and practice of iodized salt utilization and associated factors among pregnant women in debreberhan town central Ethiopia. J Med Sci. 
24. Gerensea H, Yohannse A, Baymot B, Atsbha H, Nguse K, et al. (2016) Knowledge, attitude and practice (KAP) towards iodized salt utilization in HaweltiKebelle. Edorium J Nutr Diet 222: 1-81.

25. Buxton C, Baguune B (2012) Knowledge and practices of people in Bia District, Ghana, with regard to iodine deficiency disorders and intake of iodized salt. Arch Public Heal 70(1): 1-9.

26. Vasudevan S, Senthilvel S, Sureshbabu J (2019) Knowledge attitude and practice on iodine deficiency disorder and iodine level in salt in retail and vendors among the rural population in south India: A community based observational and descriptive study. Clin Epidemiol Glob Heal 7(3): 300-305.

27. Kumma WP, Haji Y, Abdurahmen J, Mehretie Adinew Y (2018) Factors Affecting the Presence of Adequately Iodized Salt at Home in Wolaita Southern Ethiopia: Community Based Study. Int J Food Sci 1-9.

28. Gebremariam HG, Yesuf ME, Koye DN (2013) Availability of Adequately Iodized Salt at Household Level and Associated Factors in Gondar Town, Northwest Ethiopia. ISRN Public Health 2013(4): 1-6.

29. Tesfaye W Gebriel, Sahilu Assegid HA (2014) Cross-sectional Survey of Goiter Prevalence and Household Salt Iodization Levels in Assosa Town Beni Shangul-Gumuz Region West Ethiopia. J Pregnancy Child Heal 1(3): 1-6.

30. Gidey B, Alemu K, Atnafu A, Kifle M, Tefera Y, et al. (2015) Availability of Adequate Iodized Salt at Household Level and Associated Factors in Rural Communities in Laelay Maychew District, Northern Ethiopia: A Cross Sectional Study. J Nutr Heal Sci 1(4): 1-9.

31. Doctor Edao Hiso, Kedir Teji Roba (2019) Utilization of Iodized salt and Associated Factor in Zuway Dugda District, Arsi Zone. East African J Sci 13(1): 75-80.

32. Obssie GF, Ketema K, Tekalegn Y (2020) Availability of Adequately Iodized Dietary Salt and Associated Factors in a Town of Southeast Ethiopia: A Community-Based Cross-Sectional Survey. J Nutr Metab 2020: 1-7.

33. Al Dakheel MH, Haridi HK, Al Bashir BM, Al Shangiti AM, Al Shehri SN, et al. (2018) Assessment of household use of iodized salt and adequacy of salt iodization: A cross-sectional National Study in Saudi Arabia. Nutr J 17(1): 1-7.

34. Malhotra V, Thompson S, Nagaraj K (2015) A Study of Utilization of Iodized Salt in Rural Population of Nalgonda District of Telangana (India). Int J Sci Res 4(5).

35. Lowe N, Westaway E, Munir A, Tahir S, Dykes F, et al. (2015 ) Increasing awareness and use of iodised salt in a marginalised community setting in North-West Pakistan. Nutrients 7(11): 9672 9682.

36. (2015) World Health Organization. eCatalogue of indicators for micronutrient programmes.

Your next submission with Juniper Publishers
will reach you the below assets
- Quality Editorial service
- Swift Peer Review
- Reprints availability
- E-prints Service
- Manuscript Podcast for convenient understanding
- Global attainment for your research
- Manuscript accessibility in different formats
( Pdf, E-pub, Full Text, Audio)
- Unceasing customer service
Track the below URL for one-step submission
https://juniperpublishers.com/online-submission.php

